\title{
Morphological analysis and description of the ovaries of female silky sharks, Carcharhinus falciformis (Müller \& Henle, 1839)
}

\author{
Mariana G. Rêgo ${ }^{1,2}$, Fábio H. V. Hazin ${ }^{1}$, Joaquim Evêncio Neto², P. G. V. Oliveira ${ }^{1}$, Maria \\ Goretti Soares $^{2}$, Keilla Regina L. S. Torres ${ }^{2}$, Fernanda O. Lana ${ }^{1}$, Pollyana C. G. Roque ${ }^{1}$, \\ Natália L. Santos ${ }^{1}$ and Rui Coelho ${ }^{3,4}$
}

This work aims to study the female reproductive tract of silky sharks, Carcharhinus falciformis, captured in the South and Equatorial Atlantic Ocean. Samples were collected between January 2008 and March 2010 through oceanic commercial vessels that targeted tuna and swordfish, with a total of 17 females collected. The methodologies followed for analyzing the ovaries of those females included both macroscopic and histological analysis. Macroscopically, it was possible to determine that the ovaries on these sharks is suspended by mesenteries in the anterior section of the body cavity, heavily irrigated by blood vessels, and contains a wide range of oocytes. Ovaries were found in three distinct maturational stages: Stage I (Immature), Stage II (Maturing) and Stage III (Mature). Immature ovaries were small, with widths ranging from 1.0 to $3.1 \mathrm{~cm}$, and had a gelatinous or granulose internal structure; maturing ovaries were slightly larger, ranging in width between 5.2 and $6.0 \mathrm{~cm}$; mature ovaries ranged in width between 6.5 and $7.8 \mathrm{~cm}$, and had a more rounded shape and the presence of large and well developed oocytes. Under microscopic examination, it was observed that the ovaries were covered with simple epithelial tissue during the early development stages and a simple cubic epithelium in the final stages of maturation. During the initial maturation stages the epigonal organ was not differentiated from the ovary. In mature specimens, the ovary showed a simple cubic epithelium and just below this epithelium there was a layer of dense connective tissue and muscle with the presence of vitellogenic oocytes and fat cells. A thin yolk membrane enclosing the oocytes was also evident. Finally, it was possible to distinguish a zona pellucida, separating the oocytes from the follicle wall and a basal lamina between the granular layers and the teak layer.

Este trabalho tem como objetivo estudar o trato reprodutivo feminino de tubarões lombo preto, Carcharhinus falciformis, capturados no Atlântico Sul e Equatorial. As amostras foram coletadas entre janeiro de 2008 e março de 2010, através das embarcações da frota atuneira, que tem como pesca alvo o atum e espadarte, com um total de 17 fêmeas coletadas. A metodologia seguida para analisar os ovários das fêmeas incluiu a análise macroscópica e histológica. Macroscopicamente, foi possível determinar que o ovário destes tubarões, é suspenso por mesentério na seção anterior da cavidade do corpo, muito irrigada por vasos sanguíneos, contendo uma vasta gama de ovócitos. Os ovários foram encontrados em três diferentes estágios de maturação: estádio I (imaturo), estágio II (maturação) e fase III (Maturo). Ovários imaturos foram pequenos, com largura variando de 1,0 a 3,1 centímetros, e tinham uma estrutura gelatinosa ou granulosa interna; ovários em maturação foram ligeiramente maiores, variando de largura entre 5,2 e 6,0 cm; ovários maduros variaram de largura entre 6,5 e 7,8 cm, possuíam uma forma mais arredondada e a presença de ovócitos grandes e bem desenvolvidos. Ao exame microscópico, foi possível observar que os ovários foram cobertos com tecido epitelial simples durante os estágios iniciais de desenvolvimento, e um epitélio cúbico simples na fase final de maturação. Durante os estágios iniciais de maturação, o órgão epigonal não foi diferenciado do ovário. Em espécimes maduros, o ovário mostrou um epitélio cúbico simples, e só abaixo deste epitélio havia uma camada de tecido conjuntivo denso e músculo com a presença de ovócitos vitelogênicos e células de gordura. Também foi evidenciada uma membrana fina juntando os ovócitos. Finalmente, foi possível distinguir uma zona pelúcida, separando os ovócitos da parede do folículo e uma lâmina basal entre as camadas granular e da camada teca.

Key words: Elasmobranchs, Histology, Maturity, Ovary, Reproduction.

${ }^{1}$ Universidade Federal Rural de Pernambuco, Departamento de Pesca e Aquicultura, Laboratório de Oceanografia Pesqueira. Rua Dom Manoel de Medeiros s/n, Dois Irmãos, 52171-900 Recife, PE, Brazil.

${ }^{2}$ Universidade Federal Rural de Pernambuco, Departamento de Morfologia e Fisiologia Animal. Rua Dom Manoel de Medeiros s/n, Dois Irmãos, 52171-900 Recife, PE, Brasil. evencio@dmfa.ufrpe.br (JEN)

${ }^{3}$ Centro de Ciências do Mar, Universidade do Algarve. Campus de Gambelas, 8005-139 Faro, Portugal.

${ }^{4}$ Florida Program for Shark Research, Florida Museum of Natural History, University of Florida. PO Box 117800, Gainesville, FL 32611, USA. 


\section{Introduction}

All elasmobranch fishes share some reproductive characteristics such as external sexual dimorphism, internal fertilization, and existence of paired reproductive organs, apparent lack of parental care, low fertility rates, and delayed sexual maturity (Dood, 1983). However, a great diversity of embryonic development strategies exist in these fishes (Dood, 1983), and variations in their reproductive strategies, both at morphological and physiological levels, are found even within a single group.

Sharks have several different modes of reproduction, including oviparity and various versions of viviparity. These reproductive modes have traditionally been classified as oviparous, ovoviviparous and viviparous (Wourms, 1977). In viviparous sharks, the pups are born at an already welldeveloped stage, with the early life stages of the pups taking place internally in the mother's ovissac (womb). This strategy is present in $56 \%$ of all Chondrichthyan fishes. The most "primitive" forms of vivipary (lecithotrophic and ovophageal) are also known as ovoviviparous. The most derived or "advanced" (placentotrophic and uterine) are also known as matotrophic vivipary, where there is a higher degree of nutritional dependence from the embryos in relation to the mother. In this mode, the embryos receive nutrients through the yolk sac, but once those nutrients are used, the sac surface comes into close contact with the uterine wall, and tissue of both the mother and the offspring grows in close contact forming the placenta. Once the placenta is formed, nutrients can then be diverted to the embryo through the mother's bloodstream (Carrier et al. 2004).

The reproductive system of female sharks consists basically of a pair of ovaries and oviducts. The ovaries are connected to the dorsal wall of the abdominal cavity by the mesentery and have three main functions: to generate germ cells, accumulate yolk, and synthesize and secrete hormones (Hamlett et al., 1999; Koob \& Callard 1999). Some literature on the reproductive strategies of elasmobranch fishes already exists (e.g., Wourms, 1977; Wourms \& Demski, 1993), and the application of reproductive parameters for fisheries biology is commonly carried (e.g., Castro \& Mejuto, 1995; Hazin et al., 2001; Coelho \& Erzini, 2006). However, most of those studies rely on macroscopic analysis of the gonads to determine maturity stages and the basic physiological description at a microscopic level of the reproductive tract of most shark species, particularly of large oceanic sharks, is still missing from the literature.

The aforementioned being considered, the aim of this study is to describe both macroscopically and microscopically the morphology of the female reproductive tract of the silky shark, Carcharhinus falciformis (Müller \& Henle, 1839), particularly the maturity stages of the ovaries. This baseline information can in the future be used by fisheries biologists to better determine the maturity stages of this species, an important parameter for an adequate stock assessment.

\section{Material and Methods}

Samples were collected between January 2008 and March 2010. The sharks were caught by the tuna fleet that fishes along the South and Equatorial Atlantic Ocean, and that bycatches oceanic sharks.

A total of 17 females were examined. Aboard the fishing vessels, the fishery observers measured each specimen for total length (TL) and pre-caudal length (PCL) to the nearest centimeter. The viscera were removed, labeled and stored in ice. Additional information such as the geographical location, time of day, and bait used on the longline of the catch was also recorded. The samples were then sent frozen to the Fisheries and Oceanography Laboratory of the Federal Rural University of Pernambuco for processing and analysis.

Each ovary was weighed and measured for length and width. A macroscopic maturity stage was defined, according to the stages described by Stehmann (2002). For preparing the ovaries for histological analysis, each ovary was fixed in $10 \%$ formalin (in sea water solution) for 48 hours, suffering cleavage within a 24 hours interval, and then returned to the fixative solution. After fixation, the ovaries were transferred to ethanol $70 \%$ and subsequently dehydrated in ethanol in ascending order concentration, from $80 \%$ to $100 \%$. Finally each ovary was cleared in xylene and embedded in paraffin.

Once embedded in the paraffin, the material was sectioned in a microtome set for $5 \mathrm{~mm}$ width sections, having been placed on slides previously coated with MAYER albumin and kept in an oven at $37^{\circ} \mathrm{C}$ for 24 hours for drying and gluing. Subsequently, sections were stained with hematoxylin/eosinphloxine and Gomori Trichrome. The visualization of the sections was carried out on a Trinocular Biological Microscope NIKON 50i, coupled with an image system used for capturing microscopic images.

\section{Results}

\section{Macroscopic description of the ovaries}

The ovaries of the silky shark are suspended by the mesentery in the anterior portion of the abdominal cavity. There are blood vessels and the presence of follicles at the respective stages of maturity.

From the samples that were analyzed in this study, five as Stage II and nine as Stage III (Table 1).

On immature females, small ovaries with widths ranging between 1.0 and $3.1 \mathrm{~cm}$ were found. Those small ovaries had a granular or gelatinous internal structure, and the oocytes were undifferentiated, uniformly small or granular, with diameters smaller than $0.2 \mathrm{~cm}$ (Table 2).

In maturing females, ovaries were slightly larger in size, with widths ranging from 5.2 to $6.0 \mathrm{~cm}$, with transparent walls and the presence of oocytes. The oocytes were under the process of maturational differentiation, and had diameters ranging from 1.0 to $2.0 \mathrm{~cm}$ (Table 2).

Mature ovaries had an average width of $7.8 \mathrm{~cm}$, and were characterized as having a rounded shape, with large and well- 
Table 1. Relationships between the maturity stages of female silky sharks, with total length of the specimens and ovary weight.

\begin{tabular}{ccccc}
\hline Maturity stage & $\begin{array}{c}\text { Length range } \\
(\mathrm{cm})\end{array}$ & Mean \pm S.D & $\begin{array}{c}\text { Ovary } \\
\text { weight } \\
\text { Range }(\mathrm{gr} .)\end{array}$ & Mean \pm S.D \\
\hline Immature & $70-133$ & $101.5 \pm 44.54$ & $60-93$ & $76.5 \pm 23.33$ \\
Maturing & $185-200$ & $192.5 \pm 10.60$ & $110-195$ & $152.5 \pm 60.10$ \\
Mature & $240-285$ & $262.5 \pm 31.81$ & $220-405$ & $312.5 \pm 130.81$ \\
\hline
\end{tabular}

developed oocytes. Besides these large and well developed oocytes, smaller oocytes were also distinguishable, with diameters ranging between 1.0 and $1.5 \mathrm{~cm}$ which would likely develop during subsequent pregnancies. The largest oocytes (vitellogenic) had diameters ranging between 2.5 and $3.0 \mathrm{~cm}$ (Table.2). The ovaries of these mature specimens were reddish in color, and the well developed oocytes were yellow.

\section{Microscopic description of the ovaries}

Under the microscopic analysis, the ovaries were found in three distinct maturational stages: Stage I (Immature), Stage II (Maturing) and Stage III (Mature).

The ovaries were covered with plain simple epithelial tissue in the early stages of development (Fig. 1a), changing for cubic simple in the final stages of maturation (Fig. 1f). Just below the epithelium, the albuginea was distinguishable, and was composed of dense connective tissue and a region with muscle fibers (Fig. 1f). In the initial stages of maturation, the epigonal organ was not histologically discriminate from the ovary.

In mature ovaries the cubic simple epithelium was observed. Just under the epithelium, a layer of dense connective tissue and a layer of muscle was observed (Fig. 1c) with the presence of vitellogenic oocytes and fat cells (Fig. 1e). A thin vitelline membrane enclosing the oocytes was also distinguishable (Fig. 1b). There was a zona pellucida separating the oocytes from the follicle wall and a basal lamina between the granular layers and the theca layer (Fig. 1d).

\section{Discussion}

According to previous works by Dodd (1983), Hamlett et al. (1999), Koob \& Callard (1999), Carrier et al. (2004) and Hamlett (2007), the ovaries of female sharks are arranged in pairs and suspended by mesenteries in the anterior section of the abdominal body cavity, in an analogous position to the males' testicles. In several elasmobranch species, only one ovary is functional. Such is the case of the species within the genus Carcharhinus, Mustelus and Sphyrna. Oviparous species have both ovaries developed and functional, such as of the species Pristis cuspidatus and Squalus brevirostris.

Pratt (1988) observed that ovaries are composed of blood vessels, nerves and a variation of oocytes and ovogonias. The morphology can vary greatly between species; however, this variation is given mainly by the presence of vitellogenic oocytes, which varies according to the reproductive strategy (oviparity, placental and aplacental viviparity). In the case of the species focused on in this work, the silky shark, the reproductive strategy presented is viviparity and in the ovary it is possible to observe a macroscopic variation on the diameters of the vitellogenic oocytes.

Matthews (1950) and Pratt (1988) described two distinct types of ovaries: one found in Lamniform sharks and the second found on other elasmobranch species. The main organizational difference between each type is the presence of an ovarian capsule. On Lamniform sharks, this capsule is located inside the epigonal organ and produces small oocytes ranging between 3 and $5 \mathrm{~mm}$ in diameter, the latter serve as food during the ovophageal strategy adopted by this order of shark. On other elasmobranch species, the ovary is external and originates on the flat surface of the epigonal organ or may even be suspended directly from the mesovarium. This type of ovary produces eggs of relatively large sizes, usually ranging between 20 and $60 \mathrm{~mm}$ in diameter, as is the case of the silky shark focused in this study. The outer layer of the ovarian stroma is composed of many primordial follicles just below the albuginea tunica. Primordial follicles consist of a primary oocyte surrounded by a layer of large and small squamous cells of the follicle. Our findings in the ovary morphology corroborates those findings described by Hamlett (2007).

Hamlett et al. (1999) showed that granule cells of the follicular wall also show significant variation among species (e.g. within the Squaliformes) and maintain a single type of columnar cells. On the other hand, groups within the Rajidae, Dasyatidae and Chimaeridae develop heterogeneous granule cells. For example, in Urobatis jamaicensis and U. halleri, columnar cells alternate with large cubic cells containing lipids, including the granular layer; but during the folliculogenesis, a decrease in the size of these cells occurs, and they disappear before ovulation. In silky sharks, columnar cells show the same pattern during the ovarian development.

In Mustelus manazo and M. griseus, the oocytes begin their development with diameters ranging between 15-20 ìm and are coated with two to three squamous cells. When their

Table 2. Relationships between the diameter of the ovary and oocyte diameter of female silky sharks.

\begin{tabular}{ccccc}
\hline Maturity stage & $\begin{array}{c}\text { Diameter of the ovary } \\
\text { Range }(\mathrm{cm})\end{array}$ & Mean \pm S.D & $\begin{array}{c}\text { Oocyte diameter } \\
\text { Range }(\mathrm{mm})\end{array}$ & Mean \pm S.D \\
\hline Immature & $1.0-3.1$ & $2.05 \pm 1.48$ & $0.1-0.2$ & $0.15 \pm 0.07$ \\
Maturing & $5.2-6.0$ & $5.6 \pm 0.56$ & $1.0-2.0$ & $1.5 \pm 0.70$ \\
Mature & $5.8-7.8$ & $6.8 \pm 1.41$ & $3.0-4.3$ & $3.35 \pm 0.57$ \\
\hline
\end{tabular}



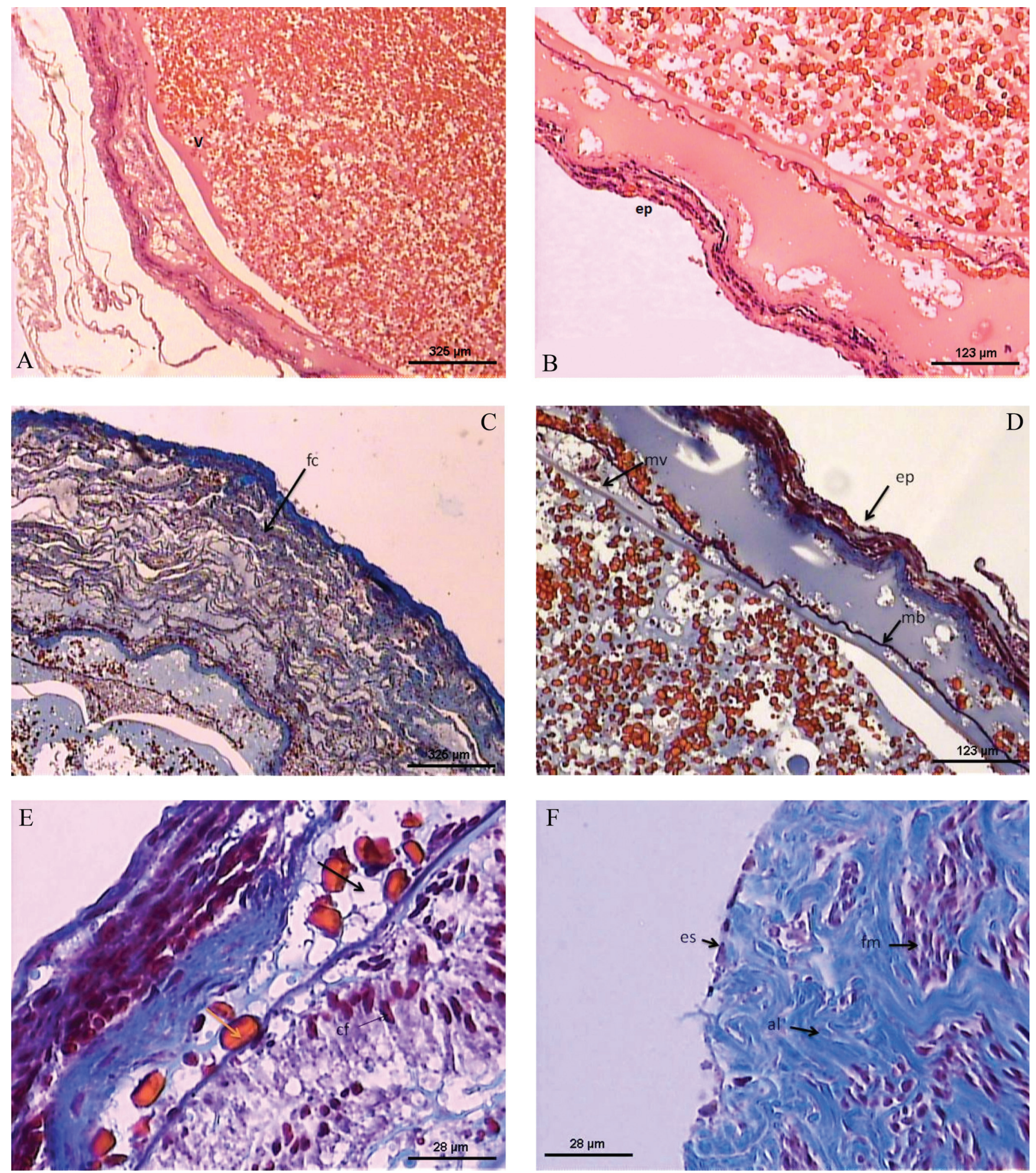

Fig. 1. Microphotograph of a mature ovary of silky shark. A - mature oocyte (yolk-rich) Staining: HE. B - epithelium (ep) and vitelline membrane (vm) Staining: HE. C - connective fibers (fc), Staining: Trichrome Gomori, D - epithelium (ep) and vitelline membrane (vm) and basal membrane (bm) Colour: HE Increase Gomori trichrome staining. E - vitelline membrane (vm), fat cells (cf), follicular cells (fc) and yolk (yk) Staining: Gomori Trichrome. F -simple epithelium (se) with cuboidal cells, albuginea composed of dense connective tissue (al) and muscle fibers regions (mf) Staining: Gomori Trichrome. 
diameter reaches $130 \mu \mathrm{m}$, the oocytes are then coated with a layer of simple squamous cells. Upon reaching $350 \mu \mathrm{m}$ in diameter, the follicular epithelium changes from simple squamous to simple cubic epithelium (Teshima, 1981). In the silky shark, a similar strategy is observed as the oocytes begin to develop.

All elasmobranch species studied so far showed evidences that the zona pellucida separates the oocytes from the follicle wall. Interestingly, the zona pellucida of two shark species (Mustelus canis and Rhizoprionodon terraenovae), whose follicular ultra-structure has been studied, is substantially thicker than in Batoids (Davenport, 2003).

The microscopic analysis of the ovaries confirmed that the Stage I is characterized by the presence of the epigonal organ undifferentiated from the ovary, thus presenting the same histological composition. In Stage II there is a decrease in the epigonal organ, and the differentiation of the ovary is more advanced, with the emergence of the first germ cells (ovogonias). In Stage III, the epigonal organ is only presented as a thin layer lining the ovary, which shows vitellogenic activity and has well developed and large oocytes.

\section{Acknowledgments}

The authors wish to acknowledge MPA, for funding the Project Ocean Sharks in Brazil. Special thanks are forwarded to all fishery observers working within this project for their cooperation in obtaining the samples during their campaigns on the fishing vessels. R. C. was supported by a grant from "FCT - Fundação para a Ciência e Tecnologia (Ref: SFRH/ BPD/40523/2007)", co-funded by "POCI-2010 - Programa Operacional Ciência e Inovacção 2010" and "FSE - Fundo Social Europeu".

\section{Literature Cited}

Carrier, J. C., H. L. Pratt Jr. \& J. I. Castro. 2004. Elasmobranch reproduction. Pp.269-286. In: Carrier, J. C., J. A. Musick \& M. R. Heithaus (Eds.). Biology of sharks and their telatives. Raton, CRC Press: Boca Raton, FL.

Castro, J. A. \& J. Mejuto. 1995. Reproductive parameters of Blue Shark, Prionace glauca, and other Sharks in the Gulf of Guinea. Marine and Freshwater Research, 46: 967-973.

Coelho, R. \& K. Erzini. 2006. Reproductive aspects of the undulate ray, Raja undulata, from the south coast of Portugal. Fisheries Research, 81: 80-85.
Davenport, I. R. 2003. Comparative morphology of oogenesis pertaining to the evolution of extreme egg size in chondrichthyan fishes. Unpublished Ph.D. Thesis. Clemson University, Clemson. 354p.

Dodd, J. M. 1983. Reproduction in cartilaginous fishes (Chondrichthyes). Pp. 31-95. In: Fish Physiology, Vol. IX Reproduction, Part A - Endocrine Tissues and Hormones (Hoar, WS, D. J. Randall \& E. M. Donaldson (Eds.). New York, Academic Press.

Hamlett, W. C., M. Jezior \& R. Spieler. 1999. Ultrastructural analysis of folliculogenesis in the ovary of the yellow spotted stingray Urolophus jamaicensis. Annals of Anatomy, 181: 159-172.

Hamlett, W. C. 2007. The Elasmobranch Ovary. Pp. 237- 281. In: Lutton, B. V., J. S. George, C. R. Murrin, L. A. Fileti \& I. P. Callard (Eds.). Reproductive biology and phylogeny of Chondrichthyes: sharks, batoids, and chimaeras. Vol. 3. Inc. Enfield (NH), USA. Science Publishers.

Hazin, F. H. V., P. G. V. Oliveira \& M. K. Broadhurst. 2001. Reproduction of the blacknose shark (Carcharhinus acronotus) in coastal waters off northeastern Brazil. Fishery Bulletin, 100: 143-148.

Koob, T. J. \& I. P. Callard. 1999. Reproductive endocrinology of female elasmobranchs: lessons from the little skate (Leucoraja erinacea) and spiny dogfish (Squalus acanthias). Journal of Experimental Zoology, 284: 557-574.

Matthews, L. H. 1950. Reproduction in the basking shark, Cetorhinus maximus (Gunner). Philosophical Transactions Royal Society Series B, 234: 247-316.

Pratt, H. L. 1988. Elasmobranch gonad structure a description and survey. Copeia, 1988: 719-729.

Stehmann, M. F. W. 2002. Proposal of a matury stages scale for oviparous and viviparous cartilaginous fishes (Pisces, Chondrichthyes). Arquive of Fishery and Marine Research. 50: 23-48.

Teshima, K. 1981. Studies on the reproduction of Japanese dogfishes, Mustelus manazo and M. griseus. Journal of the Shimonoseki University of Fisheries, 29: 113-199.

Wourms, J. P. 1977. Reproduction and development in chondrichthyan fishes. American Zoologist, 17: 379-410.

Wourms, J. P. \& Demski, L. S. 1993. The reproduction and development of sharks, skates, rays and ratfishes: introduction, history, overview, and future prospects. Environmental Biology of Fishes, 38: 7-21.

Submitted August 30, 2011

Ressubmitted May 5, 2012

Accepted October 2, 2013 by Clarice Fialho Published December 27, 2013 